\title{
Psychology of Nationalism and Religion on Example of Serbian Orthodox Church for a Period 1980-2000 (At the End of 20th Century)
}

Maja Kaninska

Ph.D. Religious Studies, Faculty of Theology, University of Ljubljana, Slovenia

\begin{tabular}{|c|c|}
\hline ARTICLE INFO & ABSTRACT \\
\hline $\begin{array}{l}\text { Keywords: } \\
\text { Psychology } \\
\text { Nationalism } \\
\text { Religion } \\
\text { Prejudices } \\
\text { Stereotypes } \\
\text { Serbian Orthodox Church }\end{array}$ & $\begin{array}{l}\text { This paper is to show nationalism through psychological perspective as } \\
\text { a world's widespread phenomenon which impacts to internal social, } \\
\text { economic and political radical changes. Religion as a nationalism itself } \\
\text { has an ideological structure, and there is a fundamental explanation for } \\
\text { that. Religion, because of its eternal character, has an exclusive, } \\
\text { omnipresent pattern with its constituent elements (religious beliefs and } \\
\text { feelings, rituals and symbols, as well as the fifth element) - and finally } \\
\text { clergy, that psychologically fulfil human spiritual needs. Influenced by, } \\
\text { usually, unpleasant historical events and many social changes, religion } \\
\text { very often played a role in maintaining some visions that have always } \\
\text { been of special significance to human. Process of secularization } \\
\text { brought to religion marginalized position in society and it was reduced } \\
\text { mainly to its elementary activity (in Christianity, those would be } \\
\text { ceremonies related to baptism, matrimony, burial). However, its } \\
\text { ideological postulates remained in the function of the new secular } \\
\text { environment and manifested themselves with recognizable religious } \\
\text { characteristics, which is given in the paper through a theoretical } \\
\text { psychological approach. }\end{array}$ \\
\hline
\end{tabular}

\section{Introduction}

Relationship between person and culture along with a national character, share a common ground where culture is a homogeneous social phenomenon. Cultural homogeneity is also formed as a consequence of socially stressful events, and as a consequence of social conflicts, such as civil wars, wars or mass migration(s). On the other hand, the heterogeneity of cultural expression of a particular society - in addition to its main cultural characteristics — reflects in different religious affiliations, and this is often related to nation's ethnic national affiliation. Role of religion or religious impact makes people homogenous. Faith often - to the high degree - determines views, customs, system of values, goals, habits, diet, daily rituals of people, as well as the attitude toward, 2005, 21s those with whom they share the same faith with. Yet, it also determines the attitude towards those of other faiths (Kecmanović, 2005:21).

Relationship between person and culture as a whole should be comprehended as a relationship between an individual and his/her behaviour. Importance of it lies in a fact that person expresses himself/herself trough his/her behaviour. The behavioural aspect also has a national character and this particular behaviour may be common to most members of a particular nation. Although the behaviour is mostly determined by the situation, it is specific to each individual alone and it shows a certain degree of permanence that is conditioned by personality of an individual. Therefore, both personality and national character of an individual bear largely stable forms of reactions to different circumstances, with the fact that the individual reacts individually, while

* Corresponding author E-mail address: jakaninska@gmail.com 
in the case of national character the reaction is a collective one - a national one. Thus, it can be said that types of behaviour that are common to most members of one particular culture, could be an expression of national character.

The paper uses time literature from the period before the 1980s, and the period during the 1990s, as well as from the more recent period from 2000. The idea is to show that the form of nationalism has an unchangeable form and the same function in social environments where it occurs. In the context of the manuscript, to show the closeness of the ideology of nationalism in psychology observed with religious ideological influences.

\section{Cultural Homogeneity and Social Identity}

The field of psychology of nationalism is developing for decades. The very nature of nationalism is precisely described in cognitive theories of psychology which were developed within the psychology of religion. Tajfel developed a theory of social identity whose set out is an identification, or identification of an individual within the social categories system. The psychological dimensions of nationalism could be interpreted in a context of close relationship between language, culture, history and of social context of a particular nation, in one hand, and the universal psychological processes which are part of a human, i.e., part of an individual, on the other. Primarily, the elements of nationalism manifested themselves as a peculiarity of a group's behaviour, that is, as a group mentality, in a sense of a national feature, but it is, in fact a matter of ethnic nationalist character. This can be seen in the behaviour of the group and not the individual, in the expression of collective feelings and in the collective way of thinking. All of these features show that the consciousness of an individual belongs to a certain social category. The category in this case can be religion, nationality and/or ethnicity.

Also, the notion of an individual's social identity is an image that one has of himself/herself as well as of his/her belonging to a certain group; this applies to subjective feeling of oneself and his/her belonging to a group, too (Kecmanović, 2004:50). This is a reason why it is important to look at one self's attitude towards his/her connections within and out of the group, for an individual has a positive perception of liaisons within the group, meanwhile having a cautious or even hostile one towards outer ones. Mentioned cautious or hostile relationship toward ones who do not belong to the inner group is a first condition for internal bonding of the group. On the other hand, while outer liaisons of the group strengthen in a positive sense, inner liaisons of the group regularly attenuate. This interpersonal process shows up in emergence of national chauvinism.

Chauvinism is emotionally inflaming ethnic hatred, preaching national exclusiveness, and it can then realize those impulses. Chauvinism is characterized as excessive and aggressive nationalism. This refers to the dominant emphasis of one's group, one's people, belittling and insulting other peoples. In periods of war or civil conflict, chauvinism is most often motivated by the persecution and oppression of other peoples, extermination.

This acculturation, according to Wolf Oschlies, did not allow the perception of the freedom of the people to allow themselves mass heterogeneity or pluralism, but allow the need of citizens to maintain or restore the old sense of security they had in the communist order. This psychological state of mind is based on communist anti-democratic initiatives. Chauvinism in such a social status, state gains strength when there is dissatisfaction in society due to economic injustice, dissatisfaction of the majority who are faced with the alleged privileges of a "less deserving" group (ethnic group or ideologically inappropriate group, Jews or ex-communists). From chauvinism, the topic of "moral crisis" is further actualized, while corruption, the rapid growth of crime is already widespread, and all this is the product of a process of rapid, almost daily rapid social transformation (Oschlies, 1992:4).

National chauvinism represents attachment to specific group of people and is reflected as animosity towards others. Of course, in this context it is interesting to mention the comparison from 1973 by the Yugoslav sociologist D. Supek: "Chauvinism is a kind of "fan mentality", 
where attachment to one's own group automatically causes aggression towards another foreign group!" (Supek, 1973:104). By this, Supek explains that group determination mechanism of anthropoid hordes comes to the fore as a form of chauvinism, but also as a distinct form of primitive or degraded social behaviour (Supek, 1973:104). In the context of the interpretation of chauvinism, refer to Sabrina Petra Ramet's study from 1994 (The Serbian Church and the Serbian Nation, in Ramet and Adamovich (eds.)). Beginning with the period of communism, one can recognize the social transformations of the village, the opposition and the freedom of opinion, which finally produced some consequences. The village, as a social connection with a living tradition, a religious centre and a developed sense of community, was sacrificed for the sake of supported industrialization. Although it is a one-party system, the opposition to communism was "the number one enemy", the language and thought were understandable and clear to everyone. The third process in communism is repression due to cultural diversity, secret police surveillance, ideological rituals and strong censorship of the media (Ramet, 1994:123), literature, film, etc.

This acculturation, according to Wolf Oschlies, did not allow the perception of the freedom of the people to allow themselves mass heterogeneity or pluralism, but allow the need of citizens to maintain or restore the old sense of security they had in the communist order. This psychological state of mind is based on communist anti-democratic initiatives. Chauvinism in such a social status, state gains strength when there is dissatisfaction in society due to economic injustice, dissatisfaction of the majority who are faced with the alleged privileges of a "less deserving" group (ethnic group or ideologically inappropriate group, Jews or ex-communists). From chauvinism, the topic of "moral crisis" is further actualized, while corruption, the rapid growth of crime is already widespread, and all this is the product of a process of rapid, almost daily rapid social transformation (Oschlies 1992:4).

From the perspective of psychology, nationalism, in its broadest cultural sense, could be defined as one's individual sense of identification with a group that speaks the same language, share the same history with, same culture, territory, etc. (as him, shares the same romantic, mythological experience of one's nation approaching an idealized model of history). Through a process based on the idea of togetherness, psychological processes are that are shaping idea of national identity are influence by the individual experience and transformed through the personal experience of an individual or a group (in this example with a nation). Nationalism identifies specific thoughts, feelings, and actions because these three, thoughts, feelings, and actions are basis of one's attachment to a particular group (Searle-White, 1973:104).

The complexity of nationalism reflects in both development and influence to subjective feelings of an individual towards the ethnic national group altogether along with his/her acceptance of needs that are often in conflict with his/her own needs, but which are accepted by an individual or the group itself. As an example, it can be mentioned a need to attack and the need to protect and defend the group. The feeling to protect and defend is focused on defending a group against 'others' and for that this feeling sets off a kind of aggression towards 'others'. Connecting with people is a relationship that ethnic nationalists insist on, and that connection is built on the basis of the experience that compatriots are brothers and sisters. Such a relationship is easily brought about in societies with uncertain economic and political situation. Being enclosed, these groups, people within a particular state and finally states themselves remain turned into their own inner reality. Meanwhile, nationalist ideology obliges mentioned groups or people - be it minorities within the state or citizens of one particular state where nationalism is main ideology - to distance themselves from 'others' who are enemies. In a group or state as such, social crisis easily opens the possibility of people's general dissatisfaction, so they seek an authoritative leader(s) who would have a solution for and "escape" from a bad situation; Yugoslav citizens, i.e., people of different nations that formed and lived in Yugoslavia, shifted toward and accepted new values that had been marginalized for a long time, and they were 
offered a church and religion as it is at the time of radical social changes in the country. In other words, shift towards church and religion in all of social strata and social classes - who at the time radically changed the old Yugoslav social and political values - gained a certain political intensity and tension.

Also- from the perspective of observing a narrower scope - a need to obey authorities is recognized. Nationalism is evident by the low threshold of tolerance towards "others". Intolerance is based on their attitude towards the nationality of "others", i.e., people who are actually of different origins. Nationalists obediently listen to so-called "Voice of ethnic national interpreters" who's subjects are predominantly seen as a matter of national interest. On the other hand, the discrepancy and disproportion in emotional discourse of nationalists is reflected in their need for personal glorification and their need to emerge from their own insignificance. The social condition that gives space to the development of nationalism enables a way out of one's own insignificance and gives himself/herself the possibility of personal respect and "significance" (Kecmanović, 2004:84). Hence, what makes nationalism adaptable in all social conditions is a fact that in ideology of ethnic nationalism both the group and the individual find something for themselves.

\section{Attitudes and Beliefs, Prejudices}

Social psychology confirms that nationalism is actually a set of attitudes and beliefs on members of other ethnic and/or national communities. Attitude consists of three components: cognitive, emotional and conative. Each of these three attitudes, according to Ehrlich's division, consists of several qualities: comprehensiveness, intensity, assessment, and individual importance. Comprehensiveness is a general belief or general attitude on a person regardless of circumstances or situation in which he/she is. The intensity of cognitive attitude includes an extent of acceptance-agreement and rejection-disagreement with a certain statement. All beliefs and attitudes can be valued on intensity scale, where zero intensity shows that person does not have an attitude. What one esteems could be presented also as an evolutionary continuum: from good to bad, from desirable to undesirable ASO. On this scale, however, there is a neutral position, where one's estimation is absent. An individual's attitude is cognitively organized, if it is composed of differentiated beliefs that are comprehensive, intense, value-determined and important for the specificity of the individual (Ehrlich, 1973:7). Trusting an individual can be of greater or lesser importance and in that sense the following is observed: partial - peripheral - central position of the attitude. The closer the attitude is to the central position, the more important it is for the individual. This means that it is difficult to influence such an attitude in order to change the belief (Kecmanović, 2004:102).

When a pre-existing attitude is so strong and inflexible that seriously distorts perception and judgment, one has prejudice (Simpson and Yinger, 1985:21). Meaning of the word 'prejudice' is: from Latin pre-, -judicium, literally 'previous judgments'. The very word in Roman Empire was related to a trial that preceded the main trial, serving as a way to determine a potential litigation social status (Encyclopaedia Parthenesis, 1877: 271). ${ }^{1}$

Prejudice - based on its broader diffusion in one particular group - is defined as an emotional and rigid attitude to another group. Such an attitude can only exist in the mind of a person who has prejudices, which means that this person categorizes another group. According to reference mentioned above, prejudices are attitudes, however, not all attitudes are prejudices. Prejudice is brought down by certain information, useful for emphasizing and putting out usually negative states or contexts, thus blinding all other information and facts. This causes all members within one group of 'others' to be apprehended as similar. "New experiences fit into the old

\footnotetext{
${ }^{1}$ Morison, J. (1877). Encyclopaedia Perthensis. Notes and Queries, 5(167), 198-b.
} 
categories by choosing only those that are in line with prejudice or stereotype. Prejudice attitudes, due to this emotional quality, are relatively stable and persistent (...). They are, after all, anchored in life experiences that are subject to drastic reorganization" (Simpson and Yinger, 1985:21). Prejudices also include false prejudices, which are categorical opinions, that is, systematic misinterpretation of facts. Prejudices are wrong characterizations of members group of "others" of a group, and these wrong characterizations are always defended by someone from "our-group" (Simpson and Yinger, 1985:21). Therefore, the structure of any social prejudice refers to extreme social groups, ethnocentrism, tempocentrism, sociocentrism, etc.

Along with attitudes, the acute mean of apprehending things and people from nationalistic point of view represents prejudice about people of other nationalities, which implies a repulsive, hostile attitude towards one person or a larger number of people just because they belong to another, certain ethnic or national group. It is believed that the very fact of belonging to another ethnic or national group makes their members to be undesirable, of bad traits, worthy for condemnation and contempt (Kecmanović, 1999:103). Prejudice is therefore a type of attitude that does not derive from experience of one party in relation to the object of prejudice, however, this inexperience is the reason why prejudice hardly can be changed (Kecmanović, 1999:103). Simpson and Yinger believe that prejudice could express both positive and negative attitudes towards subject of prejudice: positive attitudes towards compatriots, and negative attitudes towards members of other nationalities. The conative dimension of prejudice implies social distance, but for us it is far more important to interpret it in terms of stereotypes (Kecmanović, 1999:107). Based on this division, Kecmanović gives the basic causes of stereotypes:

1. Stereotypes satisfy a person's mental laziness; it is easier to believe that all people in one group have the same characteristics,

2. The tendency to notice things in easier fashion, and that in accordance with the existing common attitude/belief, than to comprehend what is contrary to them,

3. In some communities, actions of minority group(s) are easier to notice, because it is easier to notice things or emersion that belong to minority, be it mentally, or by sensing them,

4. Stereotypes are Self-fulfilling,

5. Exaggeration in differing between two groups, in case if these groups are given special names, i.e., if they are labeled. If a group of people is given a special name, the differences between "them" and "us" become much bigger than they are objectively;

6. Due to so-called halo effect, if someone has a bad trait (and who doesn't!?), we conclude that his/her other traits can't be better;

7. People could be in or take a part of a circle that spread prejudice. If someone takes a stereotype for granted and then tries to find an explanation-even a justification for some bad qualities - then he/she spreads and strengthens the stereotype (Kecmanović, 1999:108).

As noted, nationalism identifies thoughts, feelings, and actions in a cultural context, including stereotypes, which shape our perception, affect our memory and adopt new information. A tendency to remember information about groups in the best possible manner - in case if that information back up our already formed common beliefs about these groups - was also a subject of Searle-White research. Examples of stereotyping were demonstrated in a SearleWhite study when where participants were given descriptions of two groups of men along with some basic individual traits. One group was described as 'friendly', the other group as 'intellectual'. In addition to description of the group's behaviour, there was a set of descriptions of some individuals. After a period of time, participants were re-tested in order to see which of the mentioned group descriptions and individuals' description remained in their memory. Both of two groups remembered already adopted group descriptions about the second group which were given to them. This research showed that data on individuals who do not fit into a given group stereotype are not remembered by tested participants (Searle-White, 2001:14) 
Identification of inter-group behaviour develops on already established basis of differences made. In terms of explaining inter-group relations - and in order to answer questions on what a group is, what group identification is, how inter-group behaviours are recognized and distinguished from other examples of social behaviour-Tajfel uses the concept of group identification in the context of the nation. A group or nation can encompass a range between one of three components: cognitive component-in the sense that someone belongs to a group; evaluative component - in sense that the notion of group and group affiliation could have positive and negative connotations. And finally, emotional component - in the sense that both cognitive and evaluative aspect of a group or member of a group can be accompanied by emotions directed towards one's own and towards another group in certain relationships (Tajfel, 1981:230). Consensus on "who's who" is - as it could be found in Tyfel's work - in many cases shared as a categorization by a certain group of another group that is being perceived as different (Tajfel, 1981:230). However, such a consensus, if directed from the opposite direction (from other groups), may determine different types forming of criteria for internal membership to the group (Tajfel, 1981:232).

Psychological tendency called "contrast effect" is an appropriate and significant effect for nationalism based on the very important role of attitudes in perceiving an image of others. A group study based on intercultural relations on ethnocentrism with two main groups of participants (inner group, outer group) had one attitude that seemed universal - inner group was more reliable and moral than outer group. Research on participant attitudes confirmed that expected attitude existed among them and that other groups were unreliable, different and immoral to them. Attitude of group members to the statements of members of other groups represented extreme attitudes on them, and that led to less respect for the other group, which in turn emphasized the effect of contrast. In fact, the contrast effect had a potential to transform a concept that could have increased conflict. Hence this effect is both destructive and self-sustaining (Dawes, Singer, Lemons, 1972:281). This could be recognized in many media reports, where the repetition of phrases, expressions and idioms determines imposed opinion about "others" and all of it serves in defining harmful traits.

\section{The search for meaning and the chosen people}

Of course, human finds the meaning of existence in many hidden corners of his/her mind and his/her desires. It is in human nature to seek the meaning of life, and all of that and even more was provided by religion in previous centuries. Religion offered much earlier an explanation on secular matters in supernatural manner. This is a reason why religion offers an answer to the question of the meaning of human life, suffering, illness, pain, death. By eliminating religion in order to spread secularism, the belief in salvation and paradise was lost. With the loss of belief in eternal salvation, a worldly-minded meaning of human life had to be found.

By stirring up nationalist feelings reveals a new source of meaning in human existence. In the 1970s, Minogue perceived the popularity of nationalism in that it offered a sense of existence and provided an escape from triviality: "people who live in turbulent times, implicitly or explicitly, ask the question: what is happening to us? The nationalist answer is unequivocal: the nation is reborn, it fights against the enemy and for its own independence" (Minogue, 1970:32). Minogue believes that this nationalist explanation does not provide the full truth and it is possible that it often has nothing to do with the truth, but to the nationalist ideology this is of little significance. "The nationalist struggle is noble, it makes human suffering dignified, and it shows man the path of hope to follow" (Kecmanović, 2004:108). In this quote, which refers to sacrifice, that is, suffering, dignity and the path to the goal, one can recognize the basic religious spiritual guidelines that make up religious life.

The similarity between religion and nationalism is in their abstractive experience, and that refers to belief and feeling. Belief refers to the peculiarity that only what is believed in is true. 
Belief is a key approach, both for those who are religious and those who are nationalists, because that constitutes their view of the world. It is a view of the world in which the main belief among pious is that God is the one who rules life and the world. Among nationalists, it is based on the belief that their national group has exemplary and exceptional and much better characteristics compared to other nationalities (Kecmanović, 2004:108). It can be noticed that the most important emphasis for both is belief, and what is empirically provable is not of their interest at all.

Shortly after Josip Broz Tito's (1980) death, nationalists started to feel, therefore to notice changes in Yugoslav society. Thus, during 1980's a group of then young Serbian Orthodox theologians appeared in public, demanding a greater presence of the church in the society and every-day's life and its way out of confinement. The Serbian Orthodox Church, together with spiritual activists, reactivated abandoned symbols and soon became a refuge for a certain percentage of nationally oriented intelligentsia. From the very beginning, Serbian Orthodox Church insisted on the cult of national values and religious historical figures, on national history, traditional customs and traditional values. This rehabilitation of the past affected nationalism and ethnocentrism in Yugoslavia. During this period of time, the emphasis on national identity and national culture only confirmed homogenization, but also self-affirmation in relation to other national and religious affiliations. Perhaps a crucial influence to Yugoslav society in the late 1980s and early 1990s was a widespread sense of victimization. The role of the victim was associated with events from the past, especially when it comes to the period of World War II in Yugoslavia, which was transformed into a trauma by reactivating the past. During the entire social transition, in spirit of national awakening, an obligation and responsibility towards church was imposed on elementary belief that the Serbian Orthodox Church lived surrounded by enemies. This gave meaning to its uniqueness, exceptionality and the experience of a sense of belonging as part of its exceptionality.

Along with the growth of popularity and authority of Serbian Orthodox Church in media as well as in social life, grew the concept of Saint-Savahood (the construction of the Serbian experience of Orthodox Christianity, as an example of concept and thoughtful practice). SaintSavahood became an important element in forming new Serbian national identity. Rapidly, the discourse of Saint-Savahood is understood as a world's unique Serbian practice of whole Orthodox Christianity which is independent of an individual. During 1980s, discourse of SaintSavahood gained much more momentum outside boundaries of theological study and it entered to almost everyday media use.

Blaming, or accusing a certain minority or national group that is not their own helps people to give them a particular sense of meaning. This is recognized in social and national structures in Yugoslavia in the process of economic changes that began in the mid-1980s. Mentioned "search for meaning" that Kecmanović explains, refers to both religion and (ethnic) nationalism. "People spend a good part of their lives searching for its meaning. Mostly unsuccessful. This is a reason why they are very grateful when someone or something offers them an explanation, deciphers the meaning of their existence" (Kecmanović, 2004:109). Similarly, Frankl defines a human condition in sense that instinct no longer tells him/her what to do, nor does tradition tell him what to do, he/she either wants to do what others do (conformism) or does what others want him to do (totalitarianism) (Frankl, 1994:94).

Search for meaning entails another feeling: 'longing for immortality'. This 'longing' is known in religion as the pursuit of deserved immortality after this earthly life in hereafter, i.e., in paradise. With the loss of significance of religious understanding of immortality, human, searching for his/her own need, found a solution for his/her own immortal meaning. Namely, it is incomparably easier to live if we know, more precisely, if we believe that our life almost has no end (Kecmaniović, 2004:110. However, there are a few people who will attain immortality by leaving behind such a legacy of achievements to humanity. There lies a reason for solutions who 
were opened within the social communities whose members believe in immortality or-in other words - eternity of their ethnic community. Pillars of this experience are a cultural and biological connection that bonds generations from the past with the living ones, and in that manner living ones achieve this immortality of their members with the ethnic community as a whole. Therein lies the answer to the need to insist on nurturing the memory and celebrating ancestors, their graves and defending them against "foreign desecration", because all of it is about identifying with ancestors. The basic function of this nationalist model lays in the fact that the more a person helps one's own ethnic community, the more remains culturally pure from the influence of other ethnic national groups, and hence will be remembered more in the collective memory of ethnic national community (Kecmanović, 1999:130).

Nationalism offers a meaning of immortality with the idea that someone who eo ipso is a member of a national community - and the community is exceptional per se, therefore immortalas a member, shares that communal immortality (Kecmanović, 2004:111). Speaking of religious environment or a religious community, their components related to their vision of ultimate meaning, immortality, sacrifice and martyrdom, were religiously developed and still act up today. Therefore, an inseparable part of this entity is an ethical justification for martyrdom and violence. Unconditional sacrifice for the faith is martyrdom. Martyrs gain peculiar respect for their faith. "Behind every saint stands martyrdom, sacrifice for the good of the church and the good of the faithful" (Kecmanović, 2004:113). This shows the ability of nationalism to satisfy a general longing for immortality, which also Anthony Smith observes, specifically referring to how nationalism differs from other ideologies, about to mortals - primarily in what generations would think of them, not through divine judgment of the afterlife. Life gives a sense of immortality and in that distinguishes nationalism from other ideologies and belief systems of the modern world (Smith, 1995:158-159).

Religious leaders on all sides have provided excruciating details about the suffering of their own people, while paying relatively little attention to the harms inflicted by their own national group, offering instead general condemnations of human rights violations by all sides and sometimes even categorical denials of well-documented atrocities (Powers, 1998:242).

Longing for immortality offers a development of one particular idea through one of the most popular subjects, which is an integral part of the monotheistic perception of the self and God: the concept of the "chosen people". Anthony Smith dealt with this notion and in his rich opus he implies that the idea of a chosen people has a religious connotation, but in modern times this religious perspective of the old religious ideal has become universalized through specific doctrines of nationalism (1996) (Kecmanović, 2004:121). One should add a view of Manzzo who believes that this merging of older religious ideals of election with the historical doctrines of (ethnic) nationalism has significantly increased the number of conflicts. The longest and fiercest among (ethnic) national communities are those conflicts that combine cultural purification and sanctification of the elect of a certain conflicting group (Kecmanović, 2004:122). The use of the notions of selectivity and exceptionality, and comparisons with Biblical motives, has always been used successfully to justify political actions in the process of change: As an example, there is a quote from bishop Atanasije Jevtic in one of his interviews (Poslednja pobeda biće Crkva (The last win will be Church):

"The covenant is ours, so our faith is our commitment: to follow Christ, to follow him wherever He goes (as seen by the Apostle John in the Apocalypse of 144,000 pure, dressed in white robes, also being a symbolic number 12 times 12, and 12, meaning one large majority, one fullness, they follow the Lamb of God wherever he goes...). So, the Serbian people chose that covenant and that is what we also call the Holy Testament and the Kosovo vow, the Orthodox Testament, the New Testament: simply experienced by Serbs, in 
Serbian territory, in Serbian being, in Serbian history, in Serbian mentality” (Jevtić, 2003:15).

The same examples could be found when it comes to national interests and, for their sake, victims. Victims generally become national heroes and are passed on as examples and role models to their descendants. There is in the world of religion selected people who proclaim themselves saints because of their exceptional deeds.

As of now on, we came to so-called 'us and them' relationship. Division between 'us' and 'them' is visible and present in both religious and nationalist groups. Although either communities or institutions integrate people into themselves, on the other hand-oppositely - they separate them from others. Religious discourse insists on division, on 'those who are of our faith' and 'those who are not of our faith'. The tension of such relations, awakened in certain historical situations, often escalates to antagonism and hostility (119). Nationalist discourse has a developed relationship of division into 'us' and 'the others'. As Manzzo simply explains, "nationalism could not exist without the concepts of twins: national and extraneous" (Manzzo, 1996:3). A quote from Bishop Atanasije Jevtić from his speech at a gathering of Serbian politicians, Pale, 1995:

"Once again are the Serbian people on the cross in Kosovo and Metohija as well as in Dalmatia, Krajina, Slavonia, Banija, Lika, Kordun, Srem, Bosnia and Herzegovina. Its people are used to carrying the cross, as it was meant to be carried by them. At this hour, I pray that God will let us to carry the cross as dignified as ever before... Every Orthodox Serb was crucified here, along with its also crucified people from Kosovo to Jadovno, furthermore from Krajina to Borovo. May God let this crucifixion lead us into resurrection - not only of us, but also the resurrection of those who, allegedly in the name of Christ, rose against the three-fingered cross." (Jevtić, 1995)

\section{Collective, Integration, Identity}

Integrative tendency is a process that an individual who has a tendency to integrate into the whole goes through, that is, has a need of belonging to the whole. Integrative tendency is a process that shows a person's need to go beyond his personal egotism and identify with some individual greatness Kecmanović, 1999:76).

Integrative tendency is an identification with someone's individual greatness and thus, disappearing in it. In nationalist conception of entity per se, integrative tendency is recognized as an opposite attitude towards self-affirmation. This attitude is quite eye-catching, because there is a natural human tendency to confirm himself/herself individually, to confirm his/her own capabilities and peculiarities (Kecmanović, 1999:76). The question is: is there a place for individual self-assertion? It is necessary to answer this question, because along with one's internal decision towards responsibility there is a personal need for his/her self-affirmation and with it his/her integration. While integrative tendency is almost a possibility without limits, it cannot be argued for self-affirmation. And therefore, "the greater the individual's renunciation of personal identity and stronger his/her drowning into the holon, the better." One of the main reasons for that is a difference in responsibility; integrated tendencies drown individual responsibility into community which is a sole bearer of responsibility. Individuals who identify themselves with some supra-individual collectivity renounce their uniqueness and with it all responsibility as well. They decide to defend a holon on behalf of their own rights (Kecmanović, 1999:77). In fact, such a collective identity represents a community that is different from other communities. It is a denominator for all parallel functional structures in social movements. Kecmanović gave an explanation of 'collective identity' in the chapter Religion and Nationalism (Kecmanović, 2004:105-126). He actually explains how religion and nationalism provide people with a collective identity. Religious identity is certainly older than the collective or 
national one, and throughout history it has been confirmed as effective and as the most important collective identity of people. Recent history, however, shows the dominance of the national identity of a particular nation, which implies affiliation. In addition to collective identity, another important characteristic is an exclusive character of affiliation that both religion and nationalism have. Exclusivity lies in belonging to one religion or respective sect or confession and excludes even possibility belonging to another religion or respective sect or confession. This kind of exclusivity, when it comes to beliefs and emotional representations is very apparent and visible. Only in the case of observing affiliation of other believers from an ecumenical point of view - when it comes to Christianity - does concession and have tolerance in relation to national affiliations in the territorial and political framework.

"Religious nationalism is based on religious ideology and implies the identity of religious and national identity. Religious nationalism is almost as a rule of ethnic nationalism. Secular nationalism implies the connection of people in a certain territory with common laws and political processes (...). Secular nationalism is most often non-ethnic, which means that it is a territorialpolitical nationalism (Kecmanović, 2004:124).

Morally ethical behaviour, according to Mark Juergensmeyer, plays role in providing ethical frameworks of behaviour to which one has to be adhered to and obey them (Juergensmeyer, 1993:15-16). Religion determines rules of good behaviour to believers, determines which thoughts are of a good quality, therefore pleasant to God, and all of that for believers to follow the path of eternal salvation. According to the nationalist unwritten rule, the criteria of good behaviour go only to the benefit of national community. Otherwise, if someone in any way damages and weakens national community, its reputation ASO, that one suffers ethical condemnation. "Society retaliates with punishment for any excessive, aggressive expression of propensity for self-affirmation; it simply removes such an individual" (Koestler, 1976:246). In religious context, the case of such an individual is classified as to be a heretic one, such an individual is excommunicated and nowadays he/she is verbally attacked by other pious believers. One's "disobedience" or disagreement with the authority of one's own national collective community is defined as treason. Such an individual is a national traitor. As an example, it could be mentioned a case of Serbian historian Milorad Tomanić, who in 2001 published a book for which he suffered excommunication from Serbian Orthodox Church ${ }^{1}$. For reasons mentioned, identity has both individual and social features, therefore national identity is at the same time a part of individual's entity and of his/her own experience. That experience connects $\mathrm{him} / \mathrm{her}$ with specific causes that are important for understanding nationalism. Togetherness confirms that national groups are bound by predictable attitudes and thought patterns (CôteBouchard, 2017:108).

Epistemological closure is a term used by Michael Ignatieff to name a belief of nationalists that no one understands them. In the epistemological focus of logical deduction, Bouschard gives examples of closed epistemological questions. This idea has been applied to the psychological backbone of epistemological closure, which is compatible with the question of rational, justified and reasonable, epistemologically closed reasoning. The first question shows a fully usable function, while the second question leads to the same idea by introducing additional layers of interpretation of justification, rationality, and reason in epistemological closure:

1. $\mathrm{S}$ believes in untruth $(\mathrm{P})$ only because he wants $(\mathrm{P})$ to be true. What $\mathrm{S}$ wants to be true is almost never true. However, is $\mathrm{S}$ convinced that untruth $(\mathrm{P})$ is epistemologically justified, rational and reasonable?

2. $\mathrm{S}$ believes in untruth $(\mathrm{P})$ only because she heard it from someone who has always lied and $\mathrm{S}$ truly believes that her source always lies. However, is $\mathrm{S}$ sure that untruth $(\mathrm{P})$ is justified, rational, reasonable?

1 - To see: Milorad Tomanić, SPC u ratu i ratovi u njoj, Medijska knjižara Krug, Beograd, 2001 
Based on their (co) knowledge, they are trapped by their history and national specifics that are known only to them, but no one from outside can penetrate them (Ignatieff, 1996:220).

The psychological approach of observation confirms that nationalists are obsessed with the uniqueness of their national group and believe that no one in the world is close to them (Kecmanović, 1999:131).

Subjectivity and the disproportion of experience become conspicuous when nationalist feelings and ideas take over dominance in attitudes; from that moment, national groups subjectively experience status of their existence, their uniqueness and relation on how others see it all (them and their matters altogether?) of course, others have an incomplete, vague picture, because they do not understand. Kecmanovic's interpretation focuses only on so-called 'ethnic times' when this perspective is extremely dominant. He singles out two basic experiences of nationalists:

1. They do not understand us because they do not want to understand us, they do not make enough effort to understand what distinguishes us from others.

2. Others do not understand us because others are not able to understand us. It is not enough for them to know our culture, history, customs, to get to know our inclinations and aversions, but it is necessary for them to get under the skin of our national soul, which is essentially impossible. What makes us unique in the spiritual-mental sense is simply not possible to the those, who are not of our kind. ${ }^{1}$

Instrumentalization of religion and nationalism is carried out by using both religion and nationalism for purposes with no good intentions. The instrumentalization of religion and nationalism is also used in international conflicts. Religion can be drawn into a conflict if its institutions are used to mobilize the population in the name of political goals (Kecmanović, 2004:123). This position of religion itself once was "growing" in Yugoslavia. The church gained importance both in cultural area and in national discourse - if anything, that could be an example of the Serbian people - also for its homogenization and identification in relation to other national and confessional members. These conditions favoured the revitalization of religion, meanwhile nationalistic and any other kind of instrumentalization of the church (Radić, Vukomanović, 2014:181). Here it would be interesting to mention Hobsbawm, who belonged to Marxist tradition of thought, however his term "invention of tradition," took on an almost iconic meaning (Hobsbawm and Ranger, 1983)

\section{Conclusion}

Psychology of nationalism is a field of psychology that has practical and clearly demonstrated processes empirically. Religious nationalism, as well as a secular one, share a common subject, which is a subjective identity status of the community. Juergensmeyer also devoted himself to these relations, arguing that the line of separation between secular nationalism and religion was very thin and had always been thin (Juergensmeyer, 1993:16). The explanation for the rise of religious nationalism in different parts of the world is due to "the loss of faith in secular institutions that have not fulfilled the promise of political freedoms, social justice, and economic prosperity." This is especially true in non-Western countries as an integral part of foreign ideology, which needs to be fought against. Juergensmeyer also notes that religious nationalism, as an alternative to the secular, is based on the promise of a future that cannot be a failure.

As early as 1960, Hayes suggested that ethno-nationalism could emerge in modern circumstances as a substitute, or as a political continuation of religion, simply because they had much in common. "Nationalism, like any religion, brings into play not only the will, but also the

\footnotetext{
1 - https://www.b92.net/info/vesti/pregled stampe.php?yyyy=2003\&mm=05\&dd=26\&nav id=109539 4.9.2020
} 
intellect, imagination and emotions. The intellect constructs a speculative theology or mythology of nationalism. Imagination has built an unseen world around the eternal past and neverending future of our own nation. Emotions foster joy and excitement when thinking about a national god who is only good and who protects us all" (Hayes, 1960:164-165).

From these explanations and definitions given in this paper, the influential components of the psychology of nationalism and social psychology of religion in the context of nationalism, it is shown that nationalism derives from the essence of the idea of a religious relationship to society. Therefore, there is visible evidence that the lack of religiously established interpretations of the meaning of life, spiritual consolation and trust in God, all of those emotional aspects of human's spiritual life, are taken over, replaced, by nationalism. Nationalism uses these emotional needs to bring them down to earth, or in spiritual experience, to put them in a horizontal perspective. Yugoslavia, a multi-ethnic, multicultural and multi-religious state, primarily a communist one, did not have the current notion of nationalist exceptionalism in its value system. With the first economic weakness and the turns of certain political structures towards their social community (republics, today an independent states), the subjective experience of nationality, among the people, strengthened, although without a clear program for resolving economical existential weaknesses. That is why we find the basis for the interpretation of ethno-nationalism in the former Yugoslavia in Oschlies' research. Rapidly and almost violently, socio-economic and political changes were taking place (from the socialist social order, in transition, to the capitalism socio-economic system), in a society whose generations, brought up in a different cultural and pedagogical model, were not ready to adopt completely different (until yesterday, "hostile") socio-economic system. Therefore, the speed and intensity of political events affected the psychology of nationalism. It used "dormant" motives from the past (internal consequences of the Second World War, removal of the Church from the social centre, unjustly determined borders between republics) to compensate for the economic crisis, that all the time remained in the background, while focusing on political turmoil, and later the conflict.

\section{References}

Allport, Gordon, 1954, The Nature of Prejudice, Golden City, NY: Doubleday.

Côte-Bouchard, 2017, Charles, Epistemological closed questions: A reply to Greco, New Jersey: Department of Philosophy.

Dawes, R. M., Singer, D., and Lemons, F, 1972, An experimental analysis of the contrast effect and its implications for intergroup communication and the indirect assessment of attitude, (editors) Washington: Kitayama, Kerry Kawakami, M. Lynne Cooper: Journal of Personality and Social Psychology.

Frankl, E. Viktor, 1978, The Unheard Cry for Meaning, New York: Psychotherapy and Humanism, Simon and Schuster.

Frankl, E. Viktor, 1994, Zašto se niste ubili: traženje smisla življenja, Beograd: Prosveta.

Hayes, J.H. Carlton, 1960, Nationalism: A Religion, New York: Macmillan.

Hobsbawm, Eric J. and Terence Ranger (eds), 1983, The Invention of Tradition, Cambridge: Cambridge University Press.

Ignatieff, Michael, 1996, Nationalism and Toleration, in R. Caplan and J. Feffer, (eds) Europe's New Nationalism, New York, Oxford: Oxsford University Press.

Jevtić, Atanasije, 1995, Velikomučenik i Jasenovac posle Jasenovca, Beograd-Valjevo: Hrišćanska misao.

Jevtić, Atanasije, Poslednja pobeda biće Crkva, 2003, Beograd: Dveri srpske, časopis za nacionalnu kulturu i društvena pitanja br. 3-4.

Kecmanović, Dušan, 1999, Psihopolitika mržnje, Beograd: Prosveta.

Kecmanović, Dušan, 2004, Racionalno i iracionalno u nacionalizmu, Beograd: XX vek. 
Kecmanović, Dušan, 2005, Nacionalni karakter: Razm(j)ere zloupotrebe, Beograd: Nova srpska politička misao.

Koestler, Arthur, 1976, The Ghost in the Machine. London, Melbourne, Sidney, Auckland: Hutchinson of London.

LeBon, Gustave, 1995, Psychologie des Foules (The Crowd), trans. and with a new introduction by Robert A. Nye, (New Brunswick, NJ: Transaction Publishers; original work published 1895).

Manzzo A, Kathryn, 1996, Creating Boundaries. The Politics of Race and Nation. London, Boulder: Lynne Rienner Publishers.

Minogue, Kenneth, 1970, Nationalism, Baltimore: Penguin Books.

Oschlies, Wolf, 1992, Rechtsradikalismus im postkommunistischen Osteuropas. Teil 1, Fallstudien; Cologne: Bundesinstitut für ostwissenschaftliche Studien, No. 29.

Powers, F. Gerard, 1998, Religion, Conflict and Prospect for Peace in Bosnia, Croatia and Yugoslavia, in: Religion and the War in Bosnia, Atlanta: American Academy of Religion: The Religiones, ed. P. Mojzes, No. 3.

Radmila Radić, Milan Vukomanović, 2014, Religion and Democracy in Serbia since 1989: The Case of the Serbian Orthodox Church, (edit) Sabrina P. Ramet, Religion and Politics in PostSocialist Central and Southeastern Europe Challenges since 1989, UK, USA: Palgrave Studies in Religion, Politics, and Policy.

Ramet, Sabrina Petra, 1994, "Triple Chauvinism" in the New Eastern Europe, Saporo: Hokkaido University Collection of Scholarly and Academic Papers: HUSCAP.

Searle-White, Joshua, 2001, The psychology of nationalism, New York: Pelgrave.

Searle-White, Joshua, 2001, The psychology of nationalism, New York: Pelgrave.

Simpson E. George and Yinger, J. Milton (1985) Racial and Cultural Minorities: An Analysis of Prejudice and Discrimination, New York: Springer Science+Business Media LLC.

Smith, D. Anthony, 1995, Nations and nationalism in a global era. Cambridge: Polity Press Cambridge.

Supek, Rudi, 1973, Društvene predrasude: socijalno-psihološka razmatranja, Beograd: Radnička štampa.

Tajfel, Henri, 1981, Human Groups and Social Categories, Cambridge (England): Studies in Social Psychology Cambridge University Press.

Tomanić, M. (2001). Srpska crkva u ratu i ratovi u njoj. Belgrade: Medijska knjižara krug. 